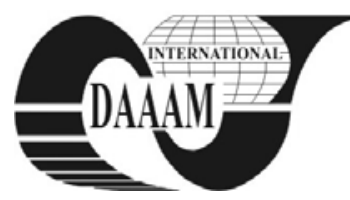

Annals of DAAAM for 2011 \& Proceedings of the 22nd International DAAAM Symposium, Volume 22, No. 1, ISSN 1726-9679 ISBN 978-3-901509-83-4, Editor B. Katalinic, Published by DAAAM International, Vienna, Austria, EU, 2011 Make Harmony between Technology and Nature, and Your Mind will Fly Free as a Bird Annals \& Proceedings of DAAAM International 2011

\title{
LASER BEAM WELDING OF ALUMINIUM
}

\section{NERADOVA, M[artina]; KOVACOCY, P[avel]; AUGUSTIN, R[obert] \& KOLENAK, R[oman]}

\begin{abstract}
This paper deals with pulsed laser welding of aluminium using an Nd:YAG laser with wavelength 1,06 $\mu \mathrm{m}$. Technically pure aluminium (95,50 wt. \%) was used as the welded material. Eighteen welds (penetration passes) were fabricated in the experiment. Optical microscopy was used to assess the influence of changes in the parameters of the pulsed laser on the quality and geometry of the penetration passes of aluminium and on the hardness measurement through the interface of the welds. The results show that the geometry of the penetration passes was influenced above all by the position of the beam focus.
\end{abstract}

Key words: welding parameters, laser welding, aluminium, weldability of aluminium

\section{INTRODUCTION}

Laser beams can be applied in a versatile manner in a wide range of technical and non-technical fields. In laser welding of materials, various types of laser devices with various power ranges are used. The automotive industry is one of many areas where laser welding of aluminum is utilized. Aluminum and its alloys are characterized by low density, relatively high strength and high corrosion resistance. They are used as structural materials in various industrial fields.

Welding of aluminum and its alloys has its specific features. Aluminum oxidizes strongly above its melting point. The oxidic layer has a high melting point, and it does not melt in the welding process . This layer has a strong ability to absorb gases and vapors, which then get into the weld metal. Oxidic particle layers may lead to the presence of oxidic inclusions in the weld metal, which deteriorates the characteristics of the welded joints.

When welding aluminum, it is necessary to use a higher intensity laser beam on the surface of the workpiece, due to the high reflectivity of aluminum. Given the high reflectivity of the radiation from the surface of aluminum, it is preferable to use just an Nd: YAG laser. Depending on the configuration and the geometry of the welds, additional materials are sometimes used for aluminum welding. When welding aluminum and its alloys, pores often form in the weld metal.. Source of these pores is hydrogen. Hydrogen has at melting temperature of aluminum relatively high solubility.

The high thermal conductivity and the high coefficient of expansion of aluminum give rise to major distortions in comparison with steel. The use of highly concentrated laser beam welding provides the preconditions for success in addressing these problems. In order to obtain high-quality welded joints, it is particularly necessary to prepare the surface prior to laser welding. The oxidic layer along the length of the surface has to be removed. This surface preparation minimizes the formation of defects in welding and the presence of pores and oxidic inclusions in the weld metal .

When welding aluminum alloys, it is essential to protect the gas bath melt from oxidation. The use of helium as the protective gas enables maximum depth for translating a high quality weld metal .

\section{EXPERIMENTAL MATERIALS}

Technically pure aluminium was used as the experimental material. The dimensions of the test samples were $76 \times 30 \times 1$ $\mathrm{mm}$. The chemical composition of $\mathrm{Al} 99.50 \%$ is shown in table 1.

\begin{tabular}{|l|l|l|l|l|l|l|}
\hline Material & \multicolumn{6}{|l|}{ Chemical composition [wt.\%] } \\
\hline $\begin{array}{l}\text { Al min } \\
99,50\end{array}$ & $\mathrm{Fe}$ & $\mathrm{Si}$ & $\mathrm{Zn}$ & $\mathrm{Cu}$ & $\mathrm{Ti}$ & others \\
\cline { 2 - 7 } & $\max$ & $\max$ & $\max$ & $\max$ & $\max$ & $\max$ \\
& 0,4 & 0,3 & 0,7 & 0,05 & 0,05 & 0,03 \\
\hline
\end{tabular}

Tab. 1. Chemical composition of $99.50 \%$

\subsection{Procedure and parameters for welding}

The experiment was executed at the International Laser Centre in Bratislava. The experimental work was performed on a W50 Laser Welder, produced by Solar Laser Systems, with wavelength $1.06 \mu \mathrm{m}$ and maximum output power $74.2 \mathrm{~J}$. During the experiments, 18 penetration passes were carried out, in which we observed the impacts of the focus location, the intensity of performance and also the impact of the energy pulse values on the geometry and integrity of the welds. Laser welding was performed in a protective atmosphere of argon with $5 \mathrm{l} / \mathrm{min}$. flow. The welding parameters are shown in table 2.

\begin{tabular}{|c|c|c|c|c|}
\hline Sample & $\mathrm{f}(\mathrm{mm})^{*}$ & $\tau(\mathrm{ms})^{*}$ & $\mathrm{U}(\mathrm{V})^{*}$ & $\mathrm{E}_{1}(\mathrm{~J})^{*}$ \\
\hline 1.1 & 5.5 & 20 & 400 & 69.8 \\
\hline 1.2 & 5.25 & 20 & 400 & 70.1 \\
\hline 1.3 & 5.0 & 20 & 400 & 70.2 \\
\hline 1.4 & 4.75 & 20 & 400 & 69.9 \\
\hline 1.5 & 4.5 & 20 & 400 & 70.0 \\
\hline 1.6 & 4.25 & 20 & 400 & 69.8 \\
\hline 1.7 & 4.0 & 20 & 400 & 70.3 \\
\hline 1.8 & 3.75 & 20 & 400 & 70.0 \\
\hline 1.9 & 3.5 & 20 & 400 & 69.1 \\
\hline 1.10 & 3.25 & 20 & 400 & 70.1 \\
\hline 1.11 & 3.0 & 20 & 400 & 70.1 \\
\hline 1.12 & 2.75 & 20 & 400 & 69.9 \\
\hline 1.13 & 2.5 & 20 & 400 & 70.1 \\
\hline 1.14 & 2.25 & 20 & 400 & 72.8 \\
\hline 1.15 & 2.0 & 20 & 400 & 74.2 \\
\hline 2.1 & 2.75 & 20 & 400 & 69.8 \\
\hline 2.2 & 2.75 & 20 & 375 & 63 \\
\hline 2.3 & 2.75 & 20 & 350 & 53.1 \\
\hline
\end{tabular}

Tab. 2. welding parameters * $\mathrm{f}(\mathrm{mm})$-standoff distance, $\tau(\mathrm{ms})$ pulse duration , $\mathrm{U}(\mathrm{V})$ - pump power, $\mathrm{E}_{1}(\mathrm{~J})$ - pulse energy 


\subsection{Assessment of penetration welds}

Optical microscopy was used for assessing the penetration welds and for measuring the hardness (HV) through the interface of the welds. Figs. 1 to 3 document the macrostructures of penetration weld 1.2 - 1.5. It follows from observing the structures that in the case of samples $1.1-1.4$ the material was not fully penetrated due to low power density.

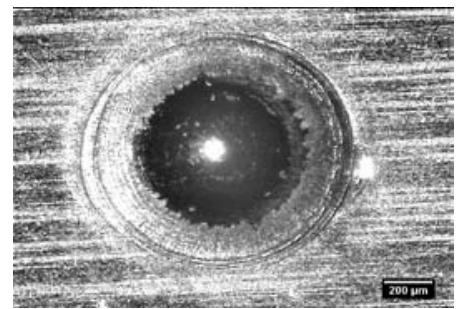

Fig. 1. Surface of penetration pass 1.5

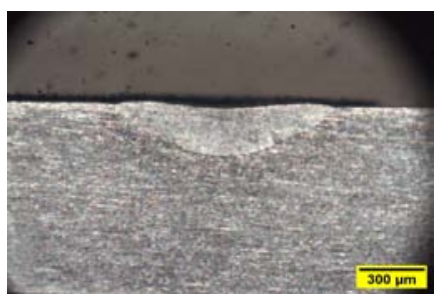

Fig. 2. Penetration pass 1.2

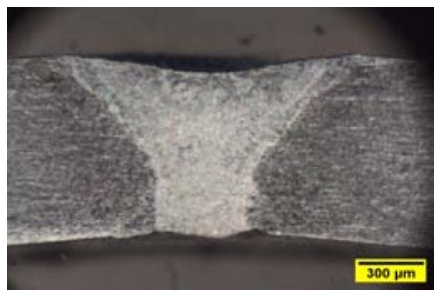

Fig. 3. Penetration pass 1.5

The surface and the root of penetration pass 1.5 are distinguished by roundness without a split. The position of the focus in relation to the surface of the material has caused the whole width of the material to be penetrated. A slight depression can be seen on the surface of the material, Fig. 3. The weld metal does not show any non-integrities or defects. The width of the surface of the penetration pass is $1.336 \mathrm{~mm}$ and the width of the root of the penetration pass is $0.872 \mathrm{~mm}$. Figs. 2 and 3 show differences in the character of the penetration. In Fig. 2, the material was not liquidized - this is known as conductional mode welding. In this mode, a thin surface layer of material is melted down and then is material heated due to the thermal conductivity. In Fig. 3, the parameters are used to produce a sufficient keyhole to enable deeper penetration of the laser beam into the material.

Vickers microhardness tests were conducted on samples 1.5, 1.9 and 2.1 .Ten measurements were made on each sample. Fig. 4 shows that the highest microhardness values were for sample 1.9. This may be due to the smaller volume of the smelted material, quicker cooling of the material, and the formation of a finer structure.

In welds 1.5, 1.9, 2.1 the highest microhardness is in the parent material. This may be because the material has been cold-rolled. The hardness drops in the heat-affected zone due to thermal processing, and on the smelting boundary and in the welding metal the hardness starts to rise. The welding metal is characterized by the pouring structure. The slight growth in the hardness of the welding metal may be due to softening of the structure.

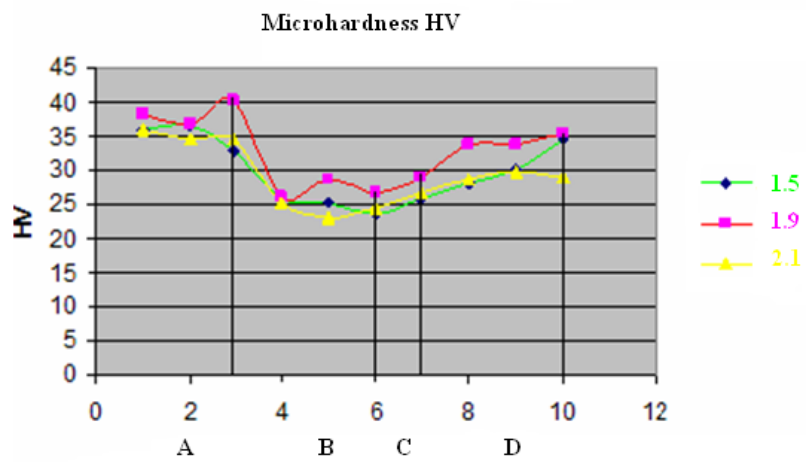

Fig. 4. Graphic illustration of the course of microhardness on samples 1.5, 1.9, $2.1 \mathrm{~A}$ - parent material, B - heat-affected zone, C - boundary of smelting, D - weld metal

\section{CONCLUSION}

Based on the results obtained in the experiment it can be stated, that the values of the standoff distance being between 0 $2 \mathrm{~mm}$ and between 4.75 - $5.5 \mathrm{~mm}$ are characterized by low penetration weld form factor (conductional welding system), which is more suitable for surface treatment of materials. A total of 10 samples were used to recast the whole thickness of the material. The standoff distance in these cases varied in the range from 2.5 - $4.5 \mathrm{~mm}$. Excitation voltage of $400 \mathrm{~V}$ was used for the production of penetrations. Because of the possibility of assessing the impact of voltage-inspiring geometry, penetration welding was carried out at voltages $350 \mathrm{~V}$ and $375 \mathrm{~V}$. Based on the measured dimensions influences of voltage energy, pulse duration and standoff distance on the weld geometry were evaluated. Based on the results of macro and microstructural analysis, it can be considered, that the most suitable parameters were used for welding the sample no. 1.5. The greatest microhardness values were measured in the base material. In the thermally influenced area a decrease in hardness was observed.

\section{ACKNOWLEDGEMENTS}

The contribution was prepared with the support of VEGA 1/0211/11 project - Development of lead-free solder for higher application temperatures and research of material solderability of metallic and ceramic materials.

\section{REFERENCES}

Ghaini, F.M et al : The relation between liquation and solidification cracks in pulsed laser welding of 2024 aluminium alloy,Materials Science and Engineering:A, Vol. 519, August 2009

I.N .Fridlyander, V.G Sister, O.E. Grushko, V.V Berstenev, L.M. Sheveleva, and L.A. Ivanova : Aluminum alloys : Promising materials in the automotive industry, Metal Science and Heat Treatment Vol.44, pp. 3 - 9, September 2002

Michna, Š., Lukáč, I., Louda, P., Očenášek. V., Schneider, H., Drápala, J., Kořený, R., Miškutová, A.., et al., Aluminium materials and Technologies from A to Z, Faculty od mechanical engenering of Liberec, Tzech Republic 2007, ISBN 978-80-89244-18-8

Turňa, M., Kovačócy, P. Zváranie laserovým lúčom. Bratislava: STU, 2003. ISBN 80-227-1921-8

Yangchun Yu, Chumming Wang, Xiyuan Hu, Jun Wang And Shengfu Yu : Porosity in fiber laser formation of 5A06 aluminum alloy, Journal of Mechanical Science and Technology 24, Springer 2010 